\title{
NERVOUS SYSTEM CANCER MORTALITY IN AN INDUSTRIALIZED AREA OF BRAZIL 1980 - 1993
}

\author{
MARCILIA DE A. MEDRADO-FARIA*, JOSÉ WILSON R. DE ALMEIDA**, \\ DIRCE M.T. ZANETTA***, GILKA J. F. GATTÁS ****
}

\begin{abstract}
Objectives: The industrialization process and nervous system cancer (NSC) mortality in a urban region of Brazil. Method: From registries of the State System of Data Analysis Foundation (SEADE), 103 males deaths by NSC (ICD-9) in Baixada Santista (BS), from 1980 to 1993 were selected. Mortality ratios were calculated comparing the standardized mortality rate for ages over 10 years old (G1) and for the age group from 35 to 64 years old, in the industrialized and non-industrialized areas in three periods: 1980-1993, 1980-86, 1987-93. Results: A statiscally significant high mortality was observed in the industrialized area, for ages over 10 in all periods and only from 1980 to 1993 for ages from 34 to 64 . The highest mortality ratio occurred from 1980-86 for ages over $10-4.12$ (CI 1.79-9.42). Conclusion: High mortality was probably related to the environmental and occupational exposure to many organic and inorganic chemical substances, considered carcinogenics, such as aliphatic and aromatic hydrocarbons, organochlorinated, formaldehyde, nitrogenated compounds and heavy metals, found in the port and industrial complex. We discuss the importance of case-control studies in characterizing the association of these and other risk factors in the determination of NSC.
\end{abstract}

KEY WORDS: occupational cancer, cancer mortality, cancer epidemiology, nervous system cancer; brain cancer.

\section{Mortalidade por câncer do sistema nervoso em uma área industrializada do Brasil 1980-1993}

RESUMO - Objetivo: Estudar o processo de industrialização e a mortalidade por câncer do sistema nervoso (CSN) em uma região urbana do Brasil. Método: Foram selecionados dos registros das Fundação Sistema Estadual de Análise de Dados Estatísticos (SEADE), 103 óbitos por CSN (ICD-9) ocorridos na Baixada Santista, no sexo masculino acima dos 10 anos, de 1980 a 1993. Calcularam-se as razões de mortalidade, padronizadas por idade, comparando as áreas industrializada e não industrializada, nos períodos de 1980-93, 1980-96 e 1987-93. Resultados: Observou-se excesso significante de mortalidade na área industrializada para a população acima de 10 anos, em todos os períodos - 3.11 (CI 1.84-5.32), 4.12 (CI 1.79-9.42) e 2.63 (CI 1.29-5.25). Para o grupo de 35-64 anos o excesso ocorreu apenas no período de 1980-93 - 2.46 (CI 1.20-5.11). Conclusão: Supõe-se que esse excesso relaciona-se à exposição ocupacional e ambiental a carcinogênicos presentes no complexo industrialportuário como: hidrocarbonetos aromáticos, órgano-clorados, compostos nitrogenados e metais. Estudos casocontrole são necessários para o estudo desses e de outros fatores de risco na determinação do CSN.

PALAVRAS-CHAVE: câncer ocupacional, mortalidade por câncer, epidemiologia do câncer, câncer do sistema nervoso.

Instituto Oscar Freire do Departamento de Medicina Legal, Ética Médica e Medicina Social e do Trabalho da Faculdade de Medicina da Universidade de São Paulo (FMUSP): *Professora-Doutora da Disciplina de Medicina Social e do Trabalho e Diretora do Serviço de Saúde Ocupacional do Hospital das Clínicas da FMUSP; **Médico do Trabalho, pesquisador da Disciplina de Medicina Social e do Trabalho da FMUSP; ***Professora do Departamento de Epidemiologia e Saúde Pública da Faculdade de Medicina de São José do Rio Preto; ****Professora-Doutora da Disciplina de Medicina Social e do Trabalho da FMUSP. Esta investigação foi financiada sob o número 030/94 pela Fundação Nacional da Saúde - CENEPI / Fundação E. de Jesus Zerbini. Aceite: 22-fevereiro-2000.

Dra. Marcilia A. Medrado-Faria - Instituto Oscar Freire, FMUSP - Rua Teodoro Sampaio 115 - 05405-000 São Paulo SP - Brasil. FAX: 8539134 E-mail: ceiof@uol.com.br 
The knowledge about occupational cancer has been expanding in the last decades due to epidemiological studies and identification of genetic and environmental elements which interfere in the oncogenenic process. Carcinogenic substances, produced and consumed in different ways in the industrialized societies, are risk factors that contribute to morbi-mortality of several kinds of cancer in many regions and countries in the world ${ }^{1-3}$. Chemical substances occupy a surmounting position in the occupational cancer etiology, as evidenced by extensive literature $\mathrm{e}^{1,3-5}$.

Nervous system cancer (NSC) has been associated in epidemiological studies with lifestyle and exposure to chemical substances and occupations in the industrial work process ${ }^{6-8}$. However, it is difficult to approach NSC due to the low frequency and diversity of diagnosis criteria. It can be classified into malignant and benign tumors; brain cancer or cancer of other nervous structures, or in some histological categories such as astrocytomas, glioblastomas, gliomas and meningiomas ${ }^{6,8-12}$. In fact, the world morbidity and mortality of NSC is low. According to Parkin 's ${ }^{2}$ estimative to the year 1985, NSC was the less frequently observed cancer,and was not classified among the 18 major cancers worldwide. Davis et al. ${ }^{10}$, observed increase in NSC mortality from 1968 to 1987 in several industrialized countries and they believe that this trend could be explained by improvement in diagnostic technics.

In the present investigation, part of the project "Cancer and Work" (The "Cancer and Work" project analyzes the morbi-mortality of different kinds of cancer related with the production and work process, industry, occupation and chemicals.), it was analyzed the distribution and evolution of male NSC mortality, from 1980 to 1993, in industrialized and non-industrialized areas in Baixada Santista (BS). This region presented the highest cancer mortality rate in State of São Paulo, Brazil ${ }^{13}$.

\section{METHOD}

The BS is an urban and industrialized region on the Southeastern coast of Brazil, next to the metropolitan area of São Paulo, which has an important metallurgical petrochemical center and the first harbor of the country. Its industries use raw materials and produce well-known carcinogenic products and input ${ }^{1,14,15}$.

\section{Strata}

In 1994 there were 1.3 million inhabitants in the BS area, distributed in eight counties: the industrial complex (harbor and industries) including Cubatão, Santos, São Vicente and Guarujá (Stratum I); and non industrialized area (apart from that complex) including Praia Grande, Monguaguá, Itanhaém and Peruíbe (Stratum II).

In 1991 both strata had subjects living mostly in the urban areas $(0.24 \%$ living in the rural area in Stratum I and $1.29 \%$ in Stratum II) ${ }^{16}$.

\section{Industrial-harbor complex}

The implantation of leather, rubber, paper and cardboard paper industries in Cubatão (148 $\mathrm{Km}^{2}$ ), a region surrounded by the coast and by the ridge, occurred in 1912, being that complex latter integrated to the Santos harbor. In the late 50's, the petroleum refineries, several petrochemical and fertilizing industries were installed and a decade later, a steel mill plant, a chloro-alkali chemical and a Portland cement industry ${ }^{17}$.

The petroleum refinery is made of three parts including distillation and cracking, petrochemical and asphalt; other nine petrochemical industries of carbon black, styrene, ethylene and polyethylene, vinyl chloride, pentachlorophenol substituted by carbon tetrachloride, methane and formaldehyde. These industries use toxicant raw materials, intermediate and final products such as: heavy metals, fluoride and organic substances (aliphatic hydrocarbons, chlorinated aliphatic hydrocarbons, aromatic hydrocarbons and polycyclic aromatic hydrocarbons) $)^{1,14,15,17,18}$.

According to the Social Information Annual List (RAIS), edited by Labor Ministry, from 1985 to 1993, the average employed population (excluding the retired people), working exclusively 
Table 1. NSC mortality in males in Baixada Santista (Brazil) in periods 1980-1993, 1980-1986 and 1987-1993.

\begin{tabular}{lcccccc}
\hline Rates* & \multicolumn{2}{c}{ Periods } \\
& $1980-1993$ & $1980-1983$ & $1987-1993$ & $\begin{array}{c}\text { Ratio } \\
1980-86 / 1987-93\end{array}$ & CI** \\
\hline ASMR*** & 2.15 & 2.30 & 1.99 & 1.15 & 0.78 & 1.72 \\
TASMR**** & 2.95 & 3.46 & 2.48 & 1.39 & 0.83 & 2.35 \\
\hline
\end{tabular}

*standardised for 1960 world population; **95\% confidence interval; ***population over 10 year-old; **** population from 35 to 64 year-old

in the industrial area, was $18.9 \%$ in Stratum I and $7.9 \%$ in Stratum II, mostly concentrated in the local small companies. The industrial workforce lived mainly in Santos and São Vicente counties and were mostly concentrated in the steel mill and petroleum refinery areas ${ }^{17}$.

\section{Mortality rates and ratios}

From State System of Data Analysis Foundation (SEADE) in São Paulo State, all males death by NSC (ICD-9 191-192), above 10 years old and resident in BS, from 1980 to 1993 were selected. The reliability of the death certificates was considered taking into account that the medical care system in BS is one of the best in Brazil. Information concerning the population was also obtained at SEADE. However, it was not possible to analyze the occupation variable because, in the great majority of cases, the death certificates just registered the term retired.

Using standardization according to the world population in 1960, the age standardized mortality rates (ASMR) for individuals over ten years of age and the truncated age standardized mortality rates (TASMR) for the truncated population from 35 to 64 years of age, for the BS area and Strata I and II, in the periods: 1980-1993, 1980-1986 and 1987-1993 were calculated. It was also calculated the ratios among the mortality rates for the Strata I and II in all periods, adopting in statistical analysis a $95 \%$ confidence interval ${ }^{19,20}$.

\section{RESULTS}

1. Mortality in BS - From 103 deaths investigated, 96 were residents in Stratum I and 7 in Stratum II. The mortality rates in the 1980-1993 period were 2.15/100 000 for the ASMR and 2.95/ 100000 for the TASMR. This last group always had higher rates (Table 1).

2. Tendency of mortality from 1980-86 to 1987-1993 - Rates decreased in this period except the ASMR in Stratum II. However, there was no statistical significance (Table 2).

3. Comparison between Strata - The ASMR has reflected an excess of mortality with statistical significance in Stratum I in all periods. The ratios in the periods 1980-1986, 1987-1993 and 19801993, were respectively: 4.12 (CI $1.79-9.42$ ), 2.63 (CI 1.29 - 5.25) and 3.11 (CI $1.84-5.32$ ). For the truncated group, the ratios have always been at least twice higher in Stratum I, but statistically significant only in the period 1980-1993 corresponding to 2.46 (CI $1.20-5.11$ ) (Table 2).

\section{DISCUSSION}

In this study the NSC excess mortality was statistically significant in the counties of the industrialized complex (Stratum I) in the BS in relation to the areas out of it. The higher difference was observed in period 1980-86, for age group over 10 year-old, with ratio 4.12 (CI 1.79-9.42). Except bladder cancer, none of other cancers (lung, oropharyngeal, colorectal, hematopoietic system, pancreas, prostate) that show excess mortality in BS, presented the ratio equal or above $3^{21}$.

In 1991 Doll $^{22}$ classified brain cancer among the 8 moderate-excess of mortality in the urban area and suggested that it could be caused by the exposure to a mixture of oils used in the urban 
areas and by chemical and rubber industry worker. The author did not analyze mortality according to levels of industrialization.

The excess of NSC can be partially explained by the exposure to many chemical substances described as neurocarcinogenic, found in the production process of the BS industrial complex. The São Paulo's Environmental Sanitation Agency (CETESB) ${ }^{14}$ reported in 1980, annual tons of carcinogenic substances in the industrial waste: dregs of petrol (4,350 tons), dregs of $\operatorname{tar}$ (832 tons), carbon black (1,319 tons), styrene and sulfur (1,200 tons); perchloroethylene, carbon tetrachloride, hexachlorobutadiene and hexachlorobenzene (912 tons); cellulose fiber residue, kaolin, titanium oxide and aniline (360 tons); naphtha, coal tar and naphthalene (12 tons); plastic bags and polyethylene grains (1,581 tons); sodium pentachlorofenate (36 tons). Besides that, among the liquid waste there were 2,600 tons of polyethylene and polyethylbenzene and 2,938 tons of tar. In the industrial complex, among input and derivatives are identified substances with severe neurotoxic actions such as mercury in the chloro-alkali industry and manganese in the steel production. According to CETESB ${ }^{14}$ the solid waste presented 122 tons of mercury, 480 tons of mercury sulphate and 135 annual tons of molybdenum, vanadium, copper, manganese and nickel.

Epidemiological studies reinforce the importance of environmental and occupational exposure in BS area when they show an association between NSC and several jobs, occupations and substances also found in that area such as: activities highlighting the petrol, petrochemical, rubber, plastic, asphalt, metals and paper industries , $^{6,11,12,23-28}$.

The solvents derived from chlorinated aliphatic hydrocarbons such as tetrachloroethylene, trichloroethylene, carbon tetrachloride, monochloromethane, trichloroethane and dichloromethane are carcinogenic agents $8,9,27,29,30$. In the case-control study, performed by Heinemann et al. ${ }^{29}$, six solvents derived from chlorinated aliphatic hydrocarbons, with mutagenic actions, had shown high significant association among astrocytomas and methyl chloride, in a matrix of occupational exposure. Vinyl chloride, polyurethane, polystyrene and polyethylene used as monomer and polymer substances in the plastic industry are also very important in the NSC etiology ${ }^{6,27}$.

Several authors have shown that the carcinogenic agents such as: high molecular weight aliphatic hydrocarbons (gasoline, diesel oil), aromatic hydrocarbons, polycyclic aromatic hydrocarbons (PAH) and polychlorinated biphenyl, increase the risk of NSC in populational groups submitted to occupational exposure (drivers, heavy-vehicle operators) and environmental pollution $6,7,31,32$.

In the production process in the BS industrial area there is also exposure to polycyclic aromatic hydrocarbons, due to the use of fuel in the industrial production (occupational and environmental risks) and the filling up of trucks and carts (occupational risk among drivers and the population in general). There is intense truck circulation from BS to the metropolitan area of São Paulo and viceversa.

Besides the chemical substances, the ionizing radiations are also considered as occupational carcinogenic agents ${ }^{28,33}$. Furthermore, the electromagnetic radiation have also been considered as occupational risk of NSC ${ }^{34,35}$. Speers et al. ${ }^{32}$ have observed higher risk among utility workers: 
electricians, electronic and communication technicians. It is believed that in great number of industries in the BS area, there might occur occupational exposure to ionizing and electromagnetic radiations.

It was observed a non-significant tendency to decrease the mortality in Stratum I in population over 10 years old as well as in age group from 35 to 64 . This reduction has also been observed for other sites of cancer such as oropharynge and bladder ${ }^{21}$. It might have been caused by the effective industrial control measures taken by governmental organization, in the BS area, from $1983 \mathrm{on}^{36}$, as shown in Table 2.

In opposition to our findings, it has been observed in many countries the tendency of increase in the incidence and mortality of the NSC in the last decades, mainly in older groups in industrialized areas. This fact has been attributed to the improvement in diagnostic techniques, ${ }^{6,10,28}$ and exposure to carcinogenic factors ${ }^{6,7,29}$. Among these, urbanization, industrialization, socioeconomic conditions, lifestyles and occupational exposure have been cited $^{11,25,37}$.

The positive association of NSC with several indicators that express high socioeconomic standards has been studied, highlighting among them: higher social class and status, higher educational level, self-employed professionals, businessmen and administrators ${ }^{6,8,11,27,28}$. On the other hand, drinking and smoking, well-known risk factors for other kinds of cancer, are not strongly associated with NSC in most studies ${ }^{33,39,40}$.

In principle, the high mortality observed by NSC in BS could not be justified by socioeconomic differences because the two Strata have similar socioeconomic conditions, typical of urban and balneal regions. On the other hand, that mortality excess could also not be explained by the tobacco use once this factor has not been considered as high risk. However, such factors must be taken into account in future studies.

The mortality excess observed in industrialized area appears to be related to the exposure to great variety of carcinogenic agents, probably in high concentration, due to inadequate spread of pollutants caused by bad ecological conditions and because of the adequate programs for the environmental and occupational pollution control in that area, were designed only from 1983 on.

Our results show the need for a deeper historical analysis of the substances used in the industrial complex in the last decades and, at the same time, of an epidemiological study of case-control morbity. This might qualify better the possible cause associations resulted from occupational and environmental exposure, as well as identify factors related to socioeconomic conditions, lifestyles and personal behavior. Besides, it might allow the approach to individual genetic aspects of susceptibilities which may improve the knowledge of oncogenetics mechanism, yet unknown in the NSC natural history.

\section{REFERENCES}

1. International Agency for Research on Cancer (IARC). IARC monographs on the evaluation of the carcinogenic risk of chemicals to humans. Lyon, 1982.

2. Parkin DM, Pisani P, Ferlay J. Estimates of the worldwide incidence of eighteen major cancers in 1985. Int J Cancer 1993;54:594-606.

3. Frumkin H. Carcinogens. In Levy BS, Wegman DH (eds). Occupational health: recognizing and preventive work-related disease. 3Ed. Boston: Little Brown, 1995:287-304.

4. MacLure KM, Macmahon E. An epidemiologic perspective of environmental carcinogenesis. Epidemiol Rev 1980; 2:19-48.

5. Lynge E. Cancer morbidity by occupation. Scand J Work Health 1992;18:50-56.

6. Thomas TL, Waxweiler RJ. Brain tumors and occupational risk factors: a review. Scand J Work Environ Heath 1986;12:1-15.

7. Kaplan S, Shimon E, Novikov I, Modan B. Occupational risks for the development of brain tumors. Am J Ind Med 1997;31:15-20.

8. Cocco P, Dosemeci M, Heineman EF. Occupational risk factors for cancer of the central nervous system: a case-control study on death certificates from 24 U.S. States. Am J Ind Med 1998;33:247-255.

9. Cordier S, Poisson M, Gerin M, Varin J, Conso F, Hemon D. Gliomas and exposure to wood preservatives. Br J Ind Med 1988;45: 705-709.

10. Davis DL, Ahlbom A, Hoel D; Percy C. Is brain cancer mortality increasing in industrial countries ? Am J Ind Med 1991;19:421-431.

11. Demers PA, Vaughan TL, Schommer RR. Occupation socioeconomic status and brain tumors mortality: a death certificate based case-control study. J Occup Med 1991;33:1001-1006. 
12. Antilla A, Heikkilã P, Nykyri E, et al. Risk of nervous system cancer among workers exposed to lead. J Occup Environ Med 1996;38:131-136.

13. Fonseca LAM. Mortalidade por câncer no Estado de São Paulo: perfil atual, distribuição geográfica e tendências temporais. Tese de Doutorado, Faculdade de Saúde Pública da Universidade de São Paulo. São Paulo, 1996.

14. Companhia de Tecnologia de Saneamento Ambiental (CETESB). Resíduos sólidos industriais na bacia do Rio Cubatão. Secretaria do Meio Ambiente do Estado de São Paulo. São Paulo, 1980 .

15. Companhia de Tecnologia de Saneamento Ambiental (CETESB). Avaliação de poluentes atmosféricos de origem industrial, na região de Cubatão: subsídios para uma política de ação. CETESB/DEAR. São Paulo, 1980.

16. Emplasa. Por dentro da Região Metropolitana da Baixada Santista. Secretaria da Fazenda do Estado de São Paulo. São Paulo, 1996.

17. Goldstein L. A industrialização da Baixada Santista: estudo de um centro industrial satélite. Tese de Doutorado, Universidade de São Paulo. São Paulo, 1972.

18. Fundacentro. Estudo das condições de higiene industrial da Companhia Siderúrgica Paulista: Cosipa. São Paulo, 1980.

19. Miettinen OS. Components of the crude risk ratio. Am J Epidemiol 1972;96:168-172.

20. Smith PG. Comparison between registries age-standardized rates. In Muir C, Waterhouse J, Mack T, Powell J, Whelan S (eds.). Cancer incidence in five continents, Vol V. Lyon: International Agency for Research on Cancer (IARC), 1987: 790-795.

21. Medrado-Faria MA, Almeida JWR . Cancer mortality in Baixada Santista SP Industrial Complex districts and others, 1980/1993. [Presented to International Conference on Environmental and Occupational Cancer in Developing Countries ; 1998 July 30-August 1 . Rio de Janeiro, Brazil.

22. Doll R. Urban and rural factors in the aetiology of cancer. Int J Cancer 1991;47:803-810.

23. Thomas TL, Decoufle P, Moure Erasco R. Mortality among workers employed in petroleum refining and petrochemical plants. J Occup Med 1980; 22: 97-103.

24. Thomas TL, Stewart PA, Stemhagen A, et al. Risk of astrocytic brain tumours associated with occupational chemical exposures. Scand J Work Environ Health 1987;13:417-423.

25. Preston-Martin S. Descriptive epidemiology of primary tumors of the brain, cranial nerves and cranial meninges in Los Angeles county. Neuroepidemiology 1989;8:283-295.

26. Hansen ES. Cancer mortality in the asphaltic industry: a ten year follow up of an occupational cohort. Br J Ind Med 1989;46:582-585.

27. Rodvall Y, Ahlbom A, Spannare B, Nise G. Glioma and occupational exposure in Sweden, a case-control study. Occup Environ Med 1996;53:526-532.

28. Gilles GG. What do we know about risk factors for glioma ? Cancer Causes Control 1997;8: 3-4.

29. Heineman EF, Cocco P, Gómez RM, et al. Occupational exposure to chlorinated aliphatic hydrocarbons and risk of astrocytic brain cancer. Am J Ind Med 1994;26:155-169.

30. Antilla A, Pukkala E, Sallmen M, Hernberg S, Hemminki K. Cancer incidence among Finish workers exposed to halogenated hydrocarbons. J Occup Environ Med 1995;37:797-806.

31. Sinks T, Steele G, Smith AB, Watkins K, Shults RA. Mortality among workers exposed to polychlorinated biphenyls. Am J Epidemiol 1992;136:389-398.

32. Speers MA, Dobbins JG, Miller VS. Occupational exposures and brain cancer mortality: a preliminary study of East Texas residents. Am J Ind Med 1988;13:629-638.

33. Berleur MP, Cordier S. The role of chemical, physical, or viral exposures and health factors in neurocarcinogenesis: implications for epidemiologic studies of brain tumors. Cancer Causes Control 1995;6:240-256.

34. Savitz DA, Loomis DP. Magnetic fields exposure in relation to leukemia and brain cancer mortality among electric utility workers. Am J Epidemiol 1995;141:123-134.

35. Guénel P, Nicolau J, Imbernon E, Chevalier A, Goldberg M. Exposure to 50-Hz electric field and incidence of leukemia, brain tumors and other cancers among french electric utility workers. Am J Epidemiol 1996;144:1107-1121.

36. Companhia de Tecnologia de Saneamento Ambiental (CETESB). Controle da poluição ambiental em Cubatão: resultados de julho 1983 a janeiro de 1987. São Paulo, 1987.

37. Smith GD, Leon D, Shipley MJ, Rose G. Socioeconomic differentials in cancer among men. Int J Epidemiol 1991; 20:339-345.

38. Eaton N, Shaddick G, Dolk H, Elliot P. Small-area study of the incidence of neoplasms of the brain and central nervous system among adults in the West Midlands region, 1974-86. Br J Cancer 1997;75:1080-1083.

39. Brownson RC, Reif JS, Chang JC, Davis JR. An Analysis of occupational risks for brain cancer. Am J Public Health 1990;80:169-172.

40. Lee M, Wrensch M, Mike R. Dietary and tobacco risk factors for adult onset glioma in the San Francisco bay area (California,USA). Cancer Causes Control 1997;8:13-24 